\title{
Pembelajaran Bahasa Indonesia \\ di Taman Pendidikan Al-Qur`an (TPA) Menggunakan Pop Up (Learning Indonesian at Al-Qur'an Learning Center Using Pop Up)
}

\author{
Syihaabul Hudaa ${ }^{\mathrm{a}, 1}$, Nuryani Nuryani ${ }^{\mathrm{a}, 2}$, dan Elen Inderasari ${ }^{\mathrm{a}, 3}$ \\ ${ }^{a}$ Institut Teknologi dan Bisnis Ahmad Dahlan, Jakarta, Indonesia \\ ${ }^{\mathrm{b}}$ Universitas Islam Negeri Syarif Hidayatullah, Jakarta, Indonesia

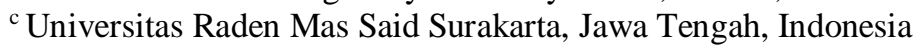 \\ ${ }^{1}$ syihaabulhudaa@itb-ad.ac.id ; ${ }^{2}$ nuryani@uinjkt.ac.id ; ${ }^{3}$ inderasari85iain@gmail.com
}

Article info ABSTRACT

Article history:

Received: 02-01-2021

Revised : 12-04-2021

Accepted: 15-05-2021

Keywords:

Indonesian language

learning

media pop up

the Al-Qu ran Learning

Center
The lack of teacher competence in making creative and informative learning media makes the learning atmosphere less pleasant. This study aims to describe the use of pop-ups in Indonesian language learning at the Al-Qur'an Learning Center (TPA). This research belongs to the type of descriptive qualitative using a classroom action research (PTK) approach. This research was conducted in August-November 2019. The stages of the research include: 1) introducing pop-ups and their manufacturing techniques, 2) the teacher applies them in Indonesian language learning activities at the TPA, and 3) describes the effectiveness of pop-up media in learning activities. The results showed that pop-up media was very effective to be applied in learning activities at the TPA. The increase in students' reading and writing skills occurs because pop-ups make students enthusiastic in learning activities.

Kurangnya kompetensi guru dalam membuat media pembelajaran yang kreatif dan informatif membuat suasana pembelajaran menjadi kurang menyenangkan. Penelitian ini bertujuan untuk mendeskripsikan penggunaan pop up pada pembelajaran bahasa Indonesia di Taman Pendidikan Al-Qur'an (TPA). Penelitian ini termasuk ke dalam jenis kualitatif deskriptif dengan menggunakan pendekatan penelitian tindakan kelas (PTK). Penelitian ini dilakukan Agustus-November 2019. Tahapan penelitian, meliputi: 1) mengenalkan pop up dan teknik pembuatannya, 2) guru menerapkan dalam kegiatan pembelajaran bahasa Indonesia di TPA, dan 3) mendeskripsikan keefektifan media pop up dalam kegiatan pembelajaran. Hasil penelitian menunjukkan bahwa media pop up sangat efektif diterapkan dalam kegiatan pembelajaran di TPA. Peningkatan kemampuan siswa dalam membaca dan menulis terjadi karena pop up membuat siswa antusias dalam kegiatan belajar.

Copyright @ 2021 Institut Agama Islam Negeri Syekh Nurjati Cirebon. All rights reserved

\section{PENDAHULUAN}

Taman Pendidikan Al-Qur`an (TPA) menjadi salah satu lembaga pembelajaran di luar sekolah yang berupaya mencerdaskan generasi muda. Selain mengajarkan materi layaknya sekolah formal, TPA mengajarkan materi bernilai religiositas. Nilai religiositas seperti sejarah Nabi, mengaji Al-Qur'an menjadi ciri khas pembelajaran di TPA. Implementasi nilai religiositas dilakukan melalui 
materi yang diajarkan dengan tujuan menciptakan generasi milenial yang berbudi pekerti yang baik.

Dalam era digital seperti saat ini, pendidikan TPA sangat penting bagi generasi muda. Hal ini dikarenakan TPA memberikan wawasan lebih kepada siswa untuk mendapatkan informasi tambahan yang tidak didapatkan di sekolah formal. Beberapa TPA yang sudah mandiri dan memiliki materi yang baik, seperti: TPA Al-Hamidiyah, TPA Nurassalam, dan TPA An-Nur yang sudah memiliki pengajaran yang baik. Di TPA yang sudah mandiri dan memiliki materi yang baik, siswa bukan hanya mendapatkan Pendidikan Al-Qur'an, melainkan pendidikan tambahan layaknya sekolah formal.

Salah satu tolok ukur pembelajaran yang berkembang adalah penggunaan media yang menarik dan beragam. Hal tersebut bertujuan menciptakan pembelajaran yang kreatif dan menyenangkan di dalam kelas. Dalam kegiatan pembelajaran di dalam kelas, terkadang seorang guru tidak mampu menyajikan pembelajaran yang menarik, sehingga siswa pun merasa bosan (Bahtiar et al., 2019). Arianti dan Herwandi menyebutkan bahwa umumnya pembelajaran dengan sistem menyimak paling banyak dilakukan di lingkungan kelas. Akan tetapi, jika teknik yang dilakukan membosankan, tentu saja siswa akan merasa bosan (Arianti \& Herwandi, 2018).

Dalam kegiatan pembelajaran di TPA sering ditemukan guru-guru yang mengajar dengan metode ceramah saja. Tentu saja hal ini membuat siswa merasa bosan dalam mengikuti kegiatan pembelajaran di TPA. Dampaknya, siswa tidak mampu menyimak pembelajaran yang diajarkan oleh guru di TPA. Selain itu, siswa aktif mengobrol dengan rekan di sebelahnya yang membuat siswa lainnya tidak fokus mengikuti kegiatan pembelajaran di TPA. Untuk itu, peranan media kreatif sangat diperlukan dalam kegiatan pembelajaran.

Salah satu media yang dikembangankan dalam proses menyimak adalah audio-visual. Audio-visual dianggap sampai saat ini merupakan media yang tepat dalam pembelajaran menyimak (Hudaa, 2018). Namun, tidak semua guru mampu membuat media pembelajaran berbasis audio-visual yang tepat. Hal ini dikarenakan kurangnya pengetahuan guru mengenai media pembelajaran yang tepat. Faktor usia, mahalnya biaya pelatihan, dan keterbatasan fasilitas membuat guru tidak terampil dalam membuat media pembelajaran (Putri et al., 2019); (Mahnun, 2012). Bahkan, lebih dari 15 guru di setiap sekolah tidak mampu membuat media pembelajaran yang menarik. Hal ini tentu saja berdampak pada pembelajaran yang monoton (Soewarno dkk., 2015).

Selain media audio-visual ada media lain yang ekonomis dan mudah digunakan yaitu pop up. Akan tetapi, tidak semua guru mau menggunakan media рор up ini. Pop up merupakan media baru di dalam dunia pendidikan era modern (Mulyaningsih \& Itaristanti, 2018). Tren penggunaan pop up lebih sering digunakan oleh pengajar BIPA di tingkat perguruan tinggi (Saddhono, 2015). Akan tetapi, pop up dapat digunakan pada siswa TPA, PAUD, dan TK agar pembelajaran di kelas menjadi menyenangkan (Putri dkk., 2019). Penggunaan media pop up sangat efektif dalam mengedukasi siswa dalam kegiatan pembelajaran (Divita \& Puspitasari, 2011). Selain itu, media pop up dianggap menjadi solusi untuk sekolah yang tidak memiliki fasilitas pembelajaran yang lengkap.

Kemajuan pendidikan dalam era modern mengharuskan seorang guru mampu mengoperasikan penggunaan berbagai media (Hudaa dkk, 2019). Hal ini 
bertujuan untuk membuat suasana pembelajaran yang menyenangkan. Peneliti bertujuan menjadikan TPA Suvainy Rava di wilayah Ciputat, Tangerang Selatan sebagai objek penelitian. Di TPA ini, tidak semua guru mampu mengoptimalisasikan penggunaan media dengan baik dan benar (Wharton, 2009). Selain itu, peneliti melalui pengabdian ini memperkenalkan media pembelajaran yang praktis dan terjangkau oleh setiap elemen masyarakat yaitu pop up. Guru TPA yang mengikuti pelatihan ini diharapkan nantinya mampu menyampaikan pembelajaran dengan menyenangkan.

Pop up masih dianggap awam oleh sebagian pengajar dan pemelajar dalam kegiatan belajar-mengajar. Hal ini dikarenakan media pop up masih menjadi media hiburan untuk anak. Bentuknya yang unik, warna yang beragam, dan mudah didapatkan di toko buku membuat pop up diminati sebagai bahan mengembangkan kreativitas anak (Kim et al., 2010). Seiring perkembangan zaman dan media, pop up dapat dimanfaatkan dalam pembelajaran bahasa (Lestari, 2016). Misalnya saja dari bentuk yang unik, dipilihkan kosakata yang tepat agar mudah diingat oleh anak. Kemudian, kata-kata tersebut dijadikan bentuk kalimat yang tersusun dengan baik (Ummi \& Mulyaningsih, 2016).

Selain itu, melalui pelatihan ini peneliti akan mengimplementasikan sistem pembelajaran yang tepat untuk digunakan dalam era modern, di mana peranan guru dan media menjadi suatu bentuk kolaborasi yang tepat (Rahardi, 2017). Melalui pelatihan yang diberikan oleh peneliti, guru TPA yang sebelumnya tidak mahir dalam menggunakan media mampu dalam mengembangkan media pembelajaran di sekolah. Selain itu, setelah mereka mahir dalam menggunakan media, diharapkan mereka mampu mengembangkan kreativitas dalam pembelajaran di dalam kelas atau di luar kelas (Azhar, 2008).

Penelitian tentang pop up sebagai media pembelajaran pernah dilakukan oleh (Zainorrahman et al., 2019) dengan judul "Pengembangan Media Berbasis Pop Up Book untuk Pembelajaran IPA di MTs Raudhatut Thalibin" di wilayah Kolor, Sumenep dengan populasi siswa sebanyak 26 orang. Hasil penelitian yang dilakukan oleh Zainorrohman menemukan bahwa pop up book dapat menjadi media pembelajaran yang efektif untuk digunakan dalam kegiatan pembelajaran. Media pop up dapat menjadi pengganti media lainnya, seperti: alat peraga, audiovisual, dan salindia.

Penelitian lainnya tentang pop up pernah dilakukan oleh Putri dkk (2019) dengan judul "Pengembangan Media Buku Pop Up untuk Meningkatkan Kemampuan Menyimak Tema Menyayangi Tumbuhan dan Hewan di Sekitar". Penelitiannya dilakukan di SD Pedurungan Kidul 04 Semarang dengan fokus pada siswa kelas III. Hasil penelitiannya menemukan bahwa buku pop up dapat memberikan wawasan dan menambah wawasan siswa dalam memahami materi yang disampaikan. Selain itu, siswa merasa tertarik mengikuti kegiatan pembelajaran dengan buku pop up.

Kemudian, penelitian lainnya tentang pop up dilakukan oleh (Lismayanti \& Hamidah, 2016) dengan judul "Pengembangan Buku Pop Up sebagai Media Pembelajaran pada Materi Crustacea untuk SMA Kelas X". Berdasarkan penelitian yang dilakukan oleh Lismayanti dan Hamidah disimpulkan bahwa penggunaan pop up layak digunakan sebagai media pembelajaran. Hal ini dikarenakan pop up mampu meningkatkan kompetensi siswa dalam materi praktik crustacea yang dilakukan oleh peneliti. 
Dari ketiga penelitian terdahulu, penelitian yang dilakukan oleh peneliti memiliki perbedaan yaitu pada siswa sasaran, jumlah siswa, dan model pop up yang digunakan. Penelitian peneliti berupaya membuat pop up sendiri dari bahan kertas karton untuk dijadikan bahan ajar pop up. Kemudian, pop up dibuat sesuai dengan materi yang diajarkan, tujuannya untuk menyesuaikan dengan kegiatan belajar-mengajar. Dengan membuat media pembelajaran sesuai dengan rencana pembelajaran, peneliti berharap media pop up dapat digunakan dengan baik dalam kegiatan pembelajaran.

Tujuan penulisan artikel ini untuk melihat keefektivitasan media pop up dalam pembelajaran bahasa Indonesia. Guru TPA yang sebelumnya hanya melakukan ceramah, melalui penelitian ini dioptimalisasikan mampu menggunakan media pop up sederhana untuk pembelajaran bahasa. Siswa TPA diharapkan tertarik dengan media baru yang digunakan oleh gurunya di dalam kegiatan belajar-mengajar.

\section{METODE}

Penelitian ini termasuk ke dalam jenis kualitatif deskriptif dengan menggunakan pendekatan penelitian tindakan kelas (Widayati, 2014). Penelitian kualitatif menekankan pada aspek deskriptif yaitu memberikan ulasan hasil penelitian dengan menggunakan teks (Moleong, 2017). Penggunaan pendekatan kualitatif dianggap mampu memberikan penjelasan secara detail dan terperinci (Creswell, 2015). Penelitian tindakan kelas dipilih dikarenakan peneliti dapat meninjau langsung suasana kelas tempat berlangsungnya penelitian (Mediyawati et al., 2019).

Tahap pertama dalam penelitian ini yaitu pengenalan media pembelajaran yang digunakan yaitu pop up. Kemudian, tahapan berikutnya yang dilakukan adalah analisis rencana pembelajaran semester. Peneliti berupaya menelaah RPS yang ada di TPA agar bisa menentukan pop up yang sesuai dengan kegiatan pembelajaran. Setelah melalui proses tersebut, peneliti mengajarkan guru membuat рор ир untuk kegiatan pembelajaran yang diimplementasikan nantinya oleh guru dalam kegiatan pembelajaran bahasa. Tujuannya tentu saja untuk melihat keefektifan pembelajaran bahasa menggunakan media pop up.

Model Kurt Lewin (Adelman, 1993) terdiri dari empat komponen, yaitu; a) perencanaan (planning), b) tindakan (acting), c) pengamatan (observing), dan d) refleksi (reflecting). Model ini dianggap tepat untuk melakukan penelitian tindakan kelas dengan menggunakan media рор ир. Hubungan keempat komponen tersebut dipandang sebagai siklus yang dapat digambarkan sebagai berikut.

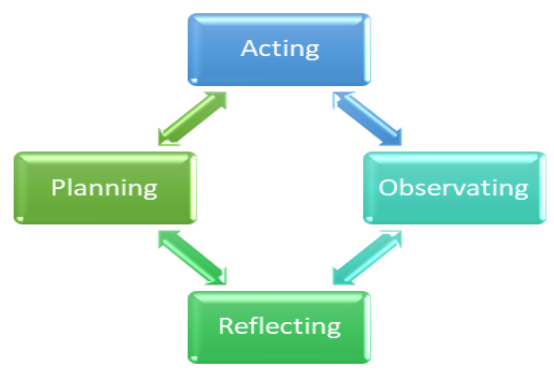

Gambar 1. Action Class Research model Lewin (Lewin, 1946) 
Penelitian ini dilakukan di TPA Suvainy Rava selama empat bulan dengan memilih kelas dengan latar belakang siswa taman kanak-kanak. Penelitian dilakukan sejak Agustus-November 2019. Sumber data dalam penelitian ini adalah siswa TPA Suvainy Rava yang menjadi objek penelitian peneliti. Sumber data dalam penelitian ini yaitu tujuh belas siswa TPA yang terdiri atas laki-laki dan perempuan dengan kualifikasi pendidikan yang sama. Kemudian, data yang didapatkan dianalisis secara deskriptif untuk disampaikan dalam pembahasan penelitian.

Dalam penelitian kualitatif, instrumen penelitian berupa pedoman observasi dan pedoman wawancara. Dengan kata lain, dalam penelitian kualitatif peneliti memiliki kesempatan untuk menelaah lebih dalam sumber data penelitian. Dalam pengembangan instrumen, peneliti berupaya melakukan beberapa tahapan, seperti: 1) membuat rencana penelitian, 2) mendesain materi penelitian, 3) menerapkan dalam penelitian dan menelaah keefektifan penelitian yang dilakukan, 4) melakukan penelitian tindakan kelas, dan 5) menelaah hasil penelitian dan menyimpulkan.

Keabsahan data dilakukan dengan menggunakan triangulasi, baik teori maupun metode. Triangulasi dilakukan untuk melakukan pengecekan kembali terhadap data-data yang telah didapatkan. Prosedur yang dilakukan oleh peneliti dalam melakukan triangulasi adalah sebegai berikut. Pertama, peneliti mendapatkan data yang berupa kegiatan pembelajaran dengan menggunakan pop up. Kedua, peneliti melakukan wawancara dengan pengajar yang menggunakan media pop up dan juga kepada siswa yang mendapatkan materi dengan menggunakan media tersebut. Wawancara ini dilakukan di luar dari wawancara utama karena tujuannya adalah untuk melakukan cek kembali atas temuan data yang dianalisis. Berdasarkan wawancara tersebut akan diketahui jika memang benar guru telah menggunakan media pop up dalam kegiatan pengajaran. Selain itu, peneliti juga menjadi lebih yakin jika peningkatan hasil belajar memang benar didapatkan setelah kegiatan pembelajaran dilakukan dengan menggunakan media tersebut. Ketiga, penelitia Kembali melihat hasil belajar siswa sebelum dan sesudah menggunakan media рор ир. Berdasarkan prosedur tersebut peneliti lebih yakin dalam membuat sebuah simpulan.

Peneliti melakukan analisis data yang meliputi tiga tahap, yakni: reduksi data, penyajian data, dan verifikasi. Reduksi data merupakan proses berpikir yang memerlukan kecerdasan, keluasaan, dan kedalaman dalam wawasan yang tinggi (Sugiyono, 2012). Peneliti dapat mendiskusikan penelitian yang dilakukan dengan rekan sejawat yang dianggap memiliki kompetensi yang baik dalam penelitian ini. Melalui proses diskusi, peneliti dapat berkembang dan dapat mengembangkan teori yang relevan. Dalam proses reduksi data, peneliti akan menyederhanakan dan membuang yan tidak diperlukan.

Setelah mereduksi data, dilakukan penyajian data secara deskriptif dengan menguraikan data temuan penelitian. Walaupun penelitian ini termasuk ke dalam jenis kualitatif, peneliti berupaya menyederhanakan data penelitian menggunakan diagram. Tujuannya untuk memudahkan pembaca memahami data yang disajikan dalam penelitian ini. Tahap terakhir yaitu melakukan verifikasi data penelitian. Verifikasi data penelitian merupakan suatu tahap terakhir dari data yang ditemukan untuk disimpulkan (Miles \& Huberman, 2012). Proses penyimpulan didukung oleh bukti-bukti yang kuat dari data yang ditemukan. Simpulan dalam 
penelitian kualitatif merupakan suatu hal baru yang belum pernah ditemukan dalam penelitian sebelumnya.

\section{HASIL DAN PEMBAHASAN}

Pop up merupakan suatu media pembelajaran yang menggunakan gambar tiga dimensi di dalam penyampaiannya. Sebagai suatu media pembelajaran, pop up menjadi suatu hal yang baru di dalam era modern seperti saat ini (Karras et al., 2017). Pop up memiliki bentuk yang unik dan menarik, sehingga membuat pemelajar tertarik menyimak materi yang sedang disampaikan. Terutama untuk siswa TPA, PAUD, TK, atau SD. Tampilannya yang menarik dan tidak membutuhkan banyak ruang, membuat pop up menjadi media pembelajaran era modern.

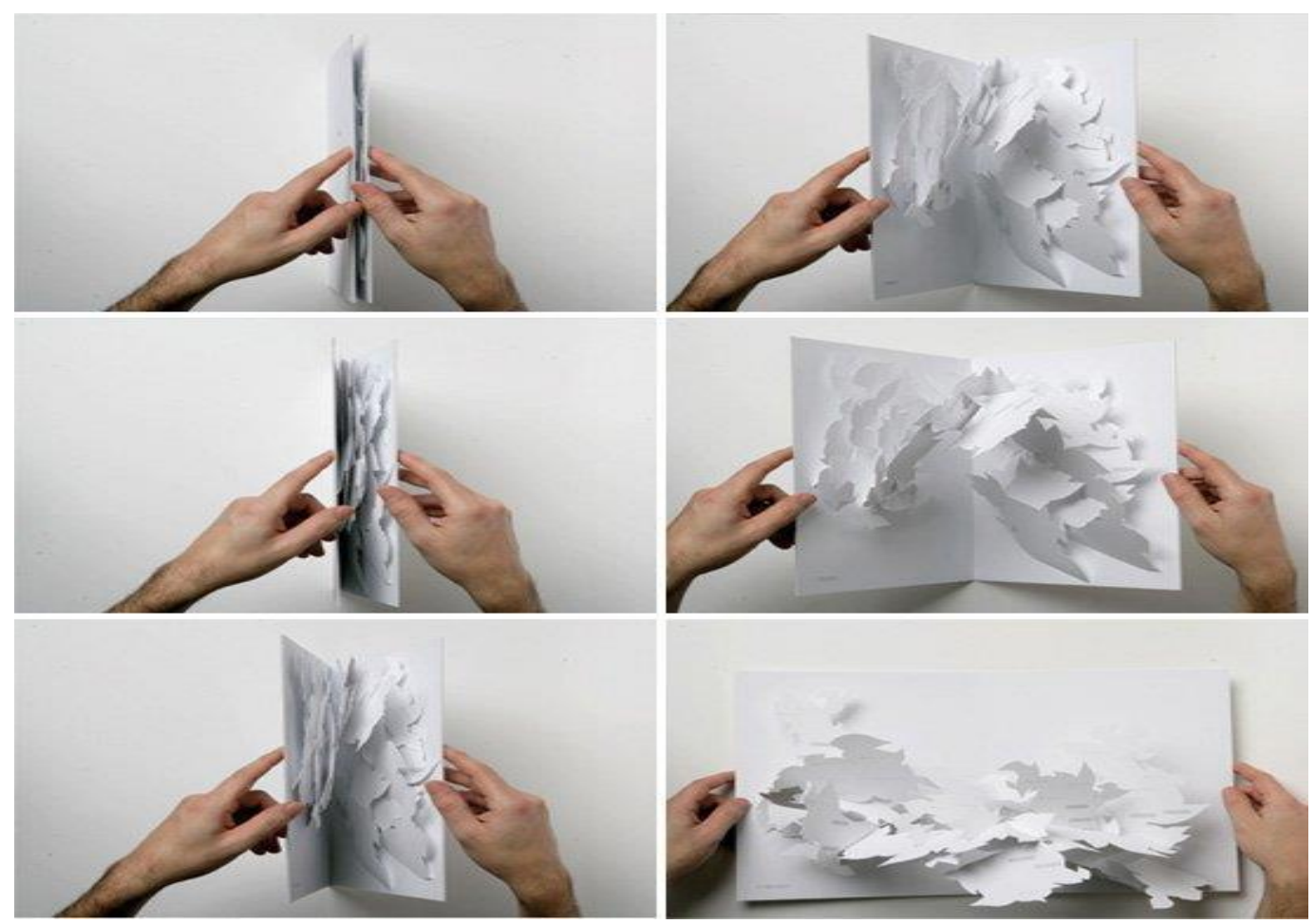

\section{Gambar 2. Pop Up Sederhana}

Pop up ditemukan pada abad ke-13, seorang biarawan Inggris, Matthew Paris, merancang sebuah perangkat kertas bergerak yang dapat diputar, volvelle, untuk bukunya yang berjudul Chronica Majorca (1236-1253). Volvelle digunakan untuk kalender keagamaan, seperti perhitungan matematis, kakulasi astronomi, alat bantu navigasi, bahkan sarana untuk meramal. Volvelle juga digunakan untuk menghitung tanggal libur umat Kristen untuk tahun-tahun yang akan datang (Divita \& Puspitasari, 2011).

Pop up hakikatnya adalah membangun suatu gambar dalam bentuk nyata. Dengan kata lain, apabila dilihat sekilas buku tersebut hanya memiliki gambar. Akan tetapi, jika diperhatikan secara detail dari gambar tersebut dapat dibangun menjadi bentu nyata yang dapat dilihat dari pelbagai sisi (Qi \& Buechley, 2010). Buku pop up yang dijual dalam bentuk buku tentu sudah 
sangat rapi. Hal ini dikarenakan buku pop up tersebut melalui proses pabrik yang berbeda dengan proses pembuatan manual. Akan tetapi, buku pop up yang diterbitkan oleh penerbit tentu saja memiliki harga yang lebih mahal.

Penggunaan pop up dahulu dikarenakan tidak adanya buku bacaan untuk anak. Pertama kali buku untuk anak diterbitkan pada paruh kedua abad ke-18 oleh penerbit Jhon Newberry. Kemudian, tahun tahun 1810 penerbit S\&J Fuller asal Inggris, mulai menerbitkan buku yang dapat dibongkar pasang. Kemudian, tahun 90-an di Indonesia buku anak yang dapat dibongkar pasang mulai familiar dan dijual secara bebas di toko buku (Divita \& Puspitasari, 2011; Hawarya \& Warso, 2014).

Selain pop up, dalam era digital pun ada jenis buku augmented reality yang memunculkan gambar lebih nyata. Akan tetapi, buku ini memerlukan gawai yang telah dipasang aplikasi sesuai dengan buku tersebut, sehingga gambar tersebut dapat terlihat nyata (Vate-U-Lan, 2012). Augmented reality yang belakangan menjadi tren di kalangan orang tua, membuat harga buku ini pun naik seiring dengan hal menarik yang didapatkan. Apabila dibandingkan dengan pop up, tentu saja buku ini memiliki perbedaan yang cukup signifikan. Pop up tidak memerlukan gawai untuk membuka hal yang menarik, sedangkan augmented reality memerlukan gawai untuk memunculkan fitur di dalamnya.

Hal inilah yang kemudian menjadi dasar bahwa buku pop up bukan hanya sebagai mainan, melainkan dapat berfungsi sebagai media pembelajaran (Wang et al., 2016). Dalam era modern seperti saat ini, pop up menjadi suatu media pembelajaran yang murah dan dapat dibentuk sesuai keinginan pembuatnya. Hal ini tentu saja disesuikan dengan RPS mengajar seorang guru di tingkat pendidikan yang diampunya. Keunggulan buku pop up tentunya melebihi buku tulis bergambar pada umumnya. Misalnya fitur tiga dimensi yang tidak dimiliki oleh buku bergambar biasa dan terkesan monoton dengan gambar yang hanya hitamputih, bahkan berwarna sekalipun. Tentu saja citra ini berbeda dengan buku pop up yang bentuknya bisa disesuaikan dan dibentuk menjadi tiga dimensi yang lebih menarik.

\section{Penerapan Pop up}

Pop up menjadi media utama di dalam penelitian yang dilakukan oleh peneliti. Hal ini dikarenakan di dalam pop up bukan saja menyajikan permainan, melainkan dapat dijadikan media pembelajaran yang interaktif antara pemelajar dengan pengajar. Di beberapa sekolah, pop up sudah tersedia dalam jumlah yang cukup banyak dan digunakan sebagai media pembelajaran. Dalam penelitian ini, peneliti berupaya mengimplementasikan pop up sederhana yang dibuat dengan mengacu pada rencana pembelajaran.

Penelitian ini dilakukan dengan melalui beberapa tahapan. Berikut uraian tahapan yang dilakukan dalam penelitian ini untuk menerapkan pop up dalam kegiatan belajar-mengajar. 


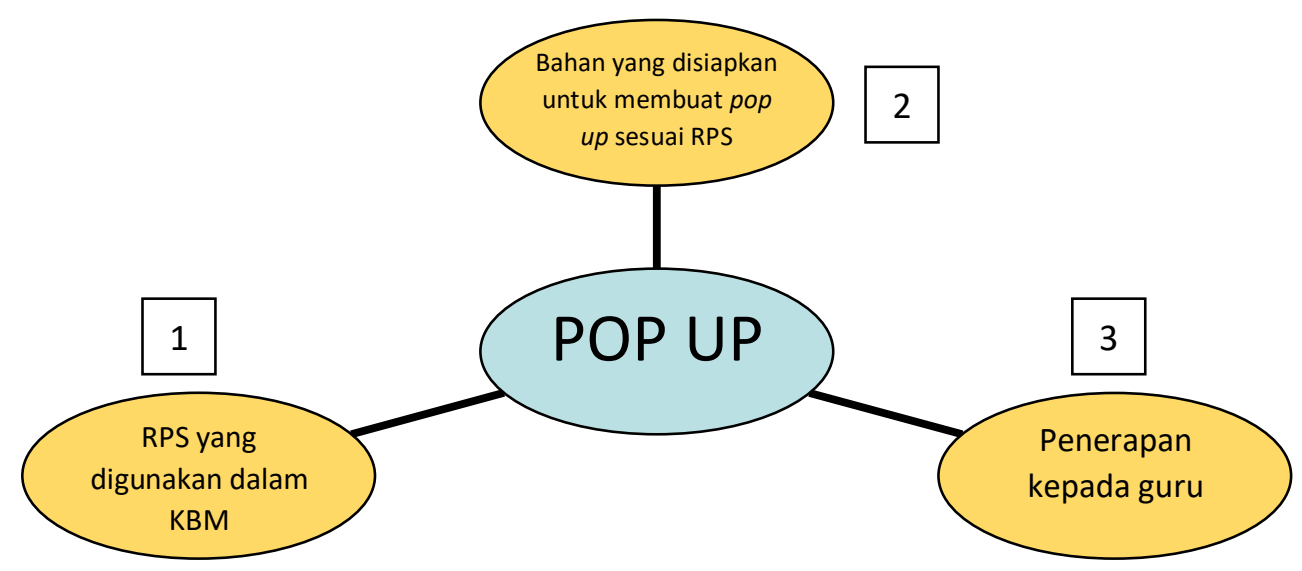

Gambar 3. Rencana Penelitian

Sebelum membuat media pop up, peneliti terlebih dahulu meninjau dan menganalisis rencana pembelajaran yang sudah dibuat oleh guru TPA. Hasil yang didapatkan dari RPS tersebut yaitu: siswa dengan kategori belum bisa membaca, terbata-bata, dan lancar. Permasalahan yang dialami oleh guru TPA yaitu siswa yang belum bisa membaca kesulitan dalam menyerap materi yang diajarkan, dikarenakan jumlah siswa yang banyak.

TPA Suvainy Rava menjadi tempat penelitian dikarenakan lokasinya yang strategis berada di sebelah UIN Syarif Hidayatullah Jakarta. Kemudian, siswa TPA ini pun cukup banyak dengan jumlah keseluruhan 84 siswa dengan latar belakang pendidikan yang berbeda. Akan tetapi, dalam penelitian ini peneliti fokus pada kelompok siswa dengan latar belakang pendidikan taman kanak-kanak dengan jumlah 17 orang siswa. Selain itu, di TPA Suvainy Rava memiliki rencana pembelajaran yang baik, sehingga peneliti memilih TPA ini sebagai tempat penelitian.

Dalam penelitian kali ini, guru diminta untuk mengajarkan siswa dengan kategori belum bisa membaca dengan jumlah siswa sebanyak 17 orang. Siswa TPA tersebut selain mengaji di TPA Suvainy Rava, bersekolah di taman kanakkanak. Tentu saja hal ini membuat guru harus mampu membuat media kreatif berupa рор ир dalam kegiatan belajar-mengajar agar menarik dan menyenangkan.

Klasifikasi bahasa yang diajarkan kepada anak yang belum membaca, terbagi atas beberapa aspek, yaitu: angka, alfabet, kemudian kata. Anak-anak yang belum bisa membaca akan dioptimalisasikan pemahamannya terlebih dahulu menggunakan media pop up yang menjelaskan tentang angka, alfabet, kemudian kata. Kemudian, mereka merangkainya menjadi kalimat sederhana.

Di TPA Suvainy Rava, tidak semua anak sudah memiliki kompetensi yang baik. Selama masa pengamatan, peneliti menemukan adanya siswa yang masih kesulitan untuk membaca dan merangkai kata menjadi kalimat. Kemudian, beberapa anak pun masih merasakan bosan dalam kegiatan belajar di TPA. Hal ini dikarenakan metode ceramah yang dianggap terlalu cepat disampaikan oleh guru di TPA.

Guru di TPA Suvainy Rava diberikan teknik pembuatan pop up yang sederhana untuk diimplementasikan ke dalam kegiatan pembelajaran. Pop up 
standar yang dibuat oleh guru, disesuaikan dengan rencana pembelajaran, sehingga guru dapat membuat media pop up yang sesuai dengan materi yang ingin disampaikan. Dalam materi bahasa Indonesia, siswa TPA dikenalkan dengan nama hewan, buah, dan kota yang kemudian dirangkaikan menjadi kalimat yang baik dan benar.

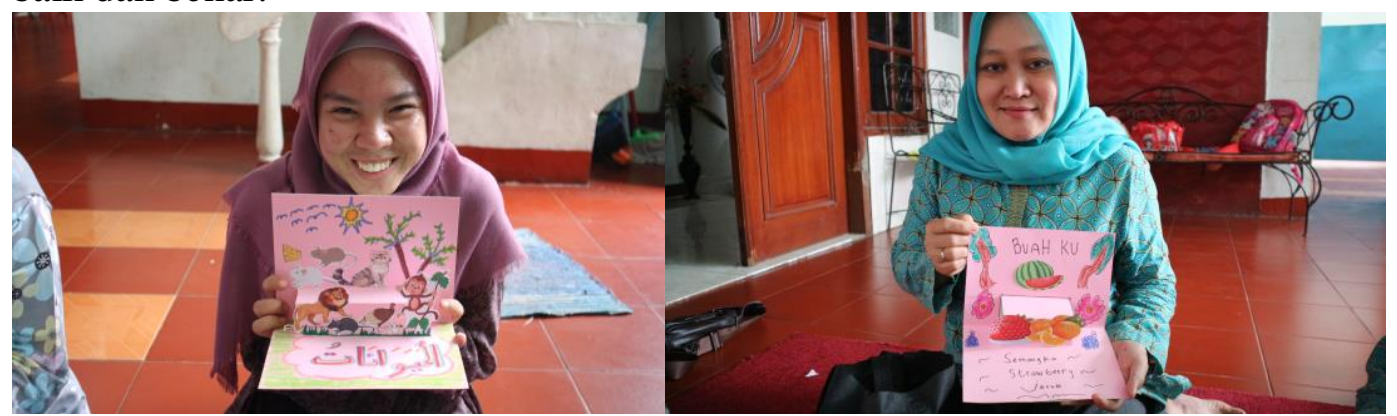

\section{Gambar 4. Media Pop Up}

Kata yang dibuat oleh guru berupa kata yang lazim digunakan oleh siswa dalam kesehariannya. Hal ini bertujuan untuk memudahkan siswa dalam membaca dan memahami kosakata yang diajarkan menggunakan media pop up. Berikut kosakata yang diajarkan oleh guru menggunakan media pop up.

Tabel 1. Contoh Kata

\begin{tabular}{cclc}
\hline \multicolumn{1}{c}{ No } & \multicolumn{1}{c}{ Hewan } & \multicolumn{1}{c}{ Buah } & Kota \\
\hline 1 & Ayam, angsa, arwana, anjing dll. & $\begin{array}{l}\text { Apel, asam, anggur, Ambon } \\
\text { arbei dll. }\end{array}$ \\
\hline
\end{tabular}

Peneliti meminta guru untuk mengajarkan bahasa dengan menggunakan cara mereka seperti biasa mengajar. Kemudian, peneliti menyimak cara guru mengajar dan menelaah keefektivitasan materi yang disampaikan oleh guru melalui ceramah. Dari hasil pengajaran guru, peneliti memberikan soal sederhana kepada siswa TPA sebanyak 17 orang siswa. Hasilnya didapatkan sebagai berikut ini.

\section{KEMAMPUAN SISWA}

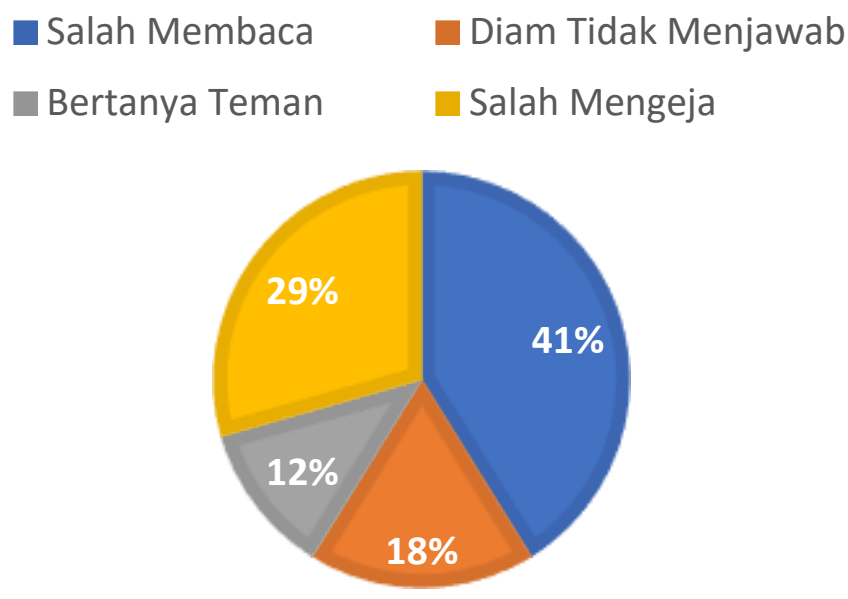

Gambar 5. Kemampuan Siswa 
Gambar 5 merupakan hasil pengamatan peneliti terhadap kemampuan siswa terkait keterampilan dalam berbahasa. Beberapa siswa yang belum bisa membaca mendapatkan kesulitan untuk membaca kosakata yang biasa mereka sebutkan di sekitar mereka. Misalnya saja kata "ayam" yang mereka bisa menyebutkan apabila melihat bentuknya, tetapi saat hanya dimunculkan katanya, mereka tidak bisa membacanya. Ketidakmampuan siswa dalam membaca murni dikarenakan siswa tersebut belum bisa membaca kata dengan baik. Akan tetapi, jika yang ditanyakan gambar, maka siswa tersebut mampu untuk menyebutkannya.

Hasil pengamatan menunjukkan bahwa siswa TPA masih belum mampu membaca dengan baik. Kategori ini diambil berdasarkan data pada siswa yang masih belum sekolah formal di tingkat sekolah dasar (SD). Sebanyak $41 \%$ siswa masih salah dalam membaca. Sebanyak $18 \%$ siswa diam tidak bisa menjawab pertanyaan yang diajukan. Sebanyak $29 \%$ siswa masih salah dalam mengeja huruf yang dituliskan oleh guru dan $12 \%$ siswa bertanya kepada teman sebelahnya saat ditanyakan oleh guru. Data tersebut diperoleh melalui soal yang diujikan kepada siswa saat kegiatan belajar. Peneliti menggunakan metode pencatatan untuk menyimak kompetensi siswa. Kemudian, data tersebut dibuat dalam persentase seperti yang disampaikan di atas.

Selanjutnya, guru melanjutkan menguji dan mengajarkan siswa dengan menggunakan media рор ир. Media рор up digunakan untuk materi yang sama seperti yang diujikan guru dalam tahap pertama. Pertanyaan masih seputar keterampilan dalam berbahasa, yaitu membaca. Jumlah siswanya pun sama dengan siklus pertama, sehingga peneliti dapat melihat keefektifan penggunaan рор up sebagai media pembelajaran. Hasil yang didapatkan pun berbeda dengan siklus pertama.

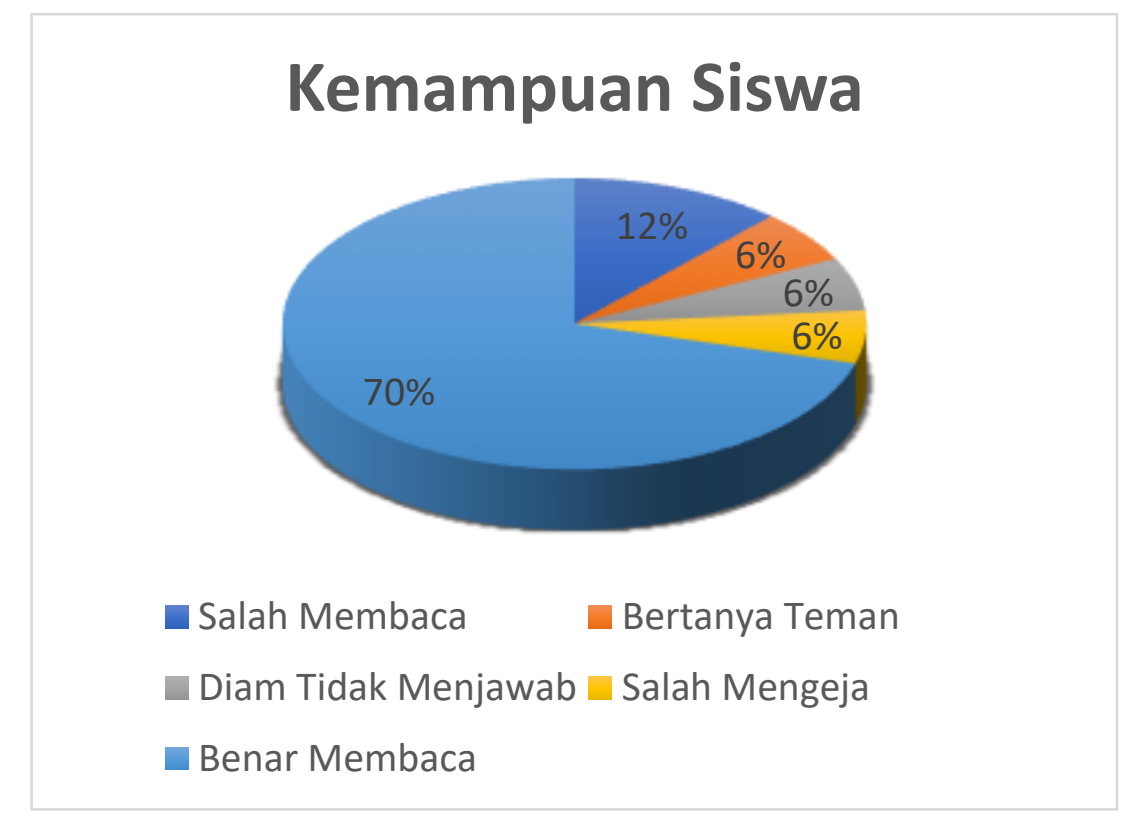

\section{Gambar 6. Kemampuan Siswa Menggunakan Media Pop Up}

Berdasarkan hasil penelitian yang dilakukan dalam menggunakan media pop up, didapatkan hasil seperti di atas. Peningkatan yang signifikan dalam siklus kedua menunjukkan bahwa siswa yang sudah mampu membaca melalui media pop up yang digunakan sebesar $70 \%$ atau sebanyak 12 orang siswa dari total 
keseluruhan 17 siswa. Akan tetapi, masih ada siswa yang salah membaca sebesar $12 \%$ atau sebanyak 2 orang siswa, salah mengeja, bertanya teman, dan diam tidak menjawab dengan persentase yang sama sebesar $6 \%$ atau sebanyak 1 orang.

Terdapat peningkatan kemampuan membaca dari pengujian sebelumnya, di mana siswa masih salah membaca sebanyak $41 \%$, tetapi di dalam pengujian menggunakan media pop up berubah menjadi $70 \%$ siswa mampu membaca dengan baik. Akan tetapi, dalam penelitian ini pun masih ada kategori siswa yang masih salah dalam membaca, salah membaca ejaan, bertanya kepada teman, dan diam tidak menjawab. Peneliti menanyakan langsung kepada siswa yang mendapatkan kesulitan dalam belajar dan menemukan beberapa faktor, seperti: 1) siswa termasuk kategori introver, 2) kurangnya latihan dalam membaca, dan 3) gangguan eksternal.

Peneliti menemukan bahwa penggunaan media pop up dapat membuat siswa tertarik mengikuti kegiatan belajar-mengajar yang dilakukan oleh guru mereka di TPA. Peningkatan ini terjadi dikarenakan pop up dianggap menarik oleh siswa TPA karena menjadi hal baru yang mereka dapatkan. Tampilan pop up membuat mereka senang mempelajari bahasa yaitu kegiatan membaca. Kemudian, mereka yang sudah mampu membaca diberikan contoh membuat kalimat sederhana, seperti: Saya memelihara ayam dua ekor di rumah. Mereka pun mampu membuat contoh kalimat sederhana dengan kata yang diberikan oleh guru mereka.

\section{Upaya yang Dilakukan Peneliti}

Berdasarkan uraian di atas, peneliti mencoba mencarikan solusi untuk guru di TPA dalam kegiatan pembelajaran. Siswa yang belum memiliki kompetensi membaca dengan baik, peneliti memberikan saran kepada guru untuk memberikan materi secara intensif. Kemudian, guru pun disarankan memberikan kesempatan kepada orang tua di rumah agar lebih mengawasi anaknya dalam belajar.

Kemudian, siswa dengan kategori introver yang ditemukan oleh peneliti harus mendapatkan pengawasan lebih. Guru disarankan untuk mengubah posisi duduk anak tersebut setiap mengikuti kegiatan pembelajaran. Selain itu, pemberian stimulus perlu dilakukan oleh guru setiap anak tersebut diberikan pertanyaan atau berpartisipasi dalam menjawab. Tujuannya tentu saja membangun rasa percaya diri di dalam dirinya.

Selanjutnya, pada permasalahan eksternal yang dihadapi guru, peneliti menyarankan perlunya membuat diskusi kelompok terpumpun dan membagi siswa. Siswa yang aktif saat kegiatan pembelajaran, sebaiknya dikelompokkan dengan siswa yang cenderung diam. Selain itu, pentingnya melakukan rotasi kelompok setiap pertemuannya agar siswa saling bekerja sama satu sama lain. Dengan dilakukan rotasi setiap pertemuannya, peneliti berupaya mengenalkan siswa satu sama lain dengan karakteristik yang berbeda.

Selain itu, peneliti menyarankan memberikan tugas lapangan di luar sekolah yang berhubungan dengan materi. Tujuannya agar siswa yang bosan belajar di sekolah dapat merasakan suasana belajar yang berbeda. Guru pun dapat memberikan materi teori dan praktik langsung kepada siswa di TPA dengan menjadikan objek sekitar sebagai materi pembelajaran. Dengan adanya suasana baru dalam kegiatan pembelajaran, peneliti berharap siswa yang sebelumnya merasakan kebosanan belajar di TPA dapat merasakan hal yang lebih menyenangkan. 


\section{SIMPULAN}

Berdasarkan penelitian yang dilakukan oleh peneliti, penggunaan pop up yang digunakan dalam penelitian dapat meningkatkan kompetensi siswa dalam membaca. Pop up yang digunakan pun dibuat oleh guru dan disesuaikan dengan materi yang disampaikan, sehingga guru dapat membuat pop up masing-masing dalam setiap pertemuan. Penggunaan media pop up yang digunakan oleh guru dapat mengefektifkan dan mengoptimalisasikan kegiatan belajar-mengajar untuk siswa TPA yang belum bisa membaca. Hal ini didasarkan pada peningkatan yang terjadi saat menggunakan pop up sebagai media, yaitu sebesar $70 \%$ atau sebanyak 12 orang siswa dari total keseluruhan 17 siswa. Namun, masih ada siswa yang salah membaca sebesar $12 \%$ atau sebanyak 2 orang siswa, salah mengeja, bertanya teman, dan diam tidak menjawab dengan persentase yang sama sebesar $6 \%$ atau sebanyak 1 orang. Dari hasil tersebut dapat disimpulkan bahwa media рор up dapat digunakan untuk pembelajaran bahasa Indonesia di TPA. Siswa yang belum bisa membaca akan tertarik untuk belajar membaca dengan adanya media belajar berupa pop up.

\section{UCAPAN TERIMA KASIH}

Peneliti mengucapkan terima kasih kepada TPA Suvainy Rava yang telah bersedia membantu peneliti sampai penelitian ini selesai. Ucapan terima kasih tidak lupa disampaikan untuk LP3M Institut Teknologi dan Bisnis Ahmad Dahlan Jakarta yang telah memfasilitasi penelitian ini dari aspek materi dan dukungan lainnya.

\section{DAFTAR PUSTAKA}

Adelman, C. (1993). Kurt Lewin and the Origins of Action Research. Educational Action Research, 1(1), 7-24. https://doi.org/10.1080/0965079930010102

Arianti, R., \& H, H. (2018). Penerapan Model Quantum Teaching Dalam Pembelajaran Menyimak Cerita Pendek. Dialektika: Jurnal Bahasa, Sastra, dan Pendidikan Bahasa dan Sastra Indonesia, 5(1), 75-89. https://doi.org/10.15408/dialektika.v5i1.7613

Azhar, A. (2008). Media Pembelajaran. Media Pembelajaran. Jakarta: Raja Grafindo. https://doi.org/media pembelajaran

Bahtiar, A., Nuryani, \& Hudaa, S. (2019). Khazanah Bahasa: Memaknai Bahasa Indonesia dengan Baik dan Benar. Bogor: In Media. http://penerbitinmedia.co.id/search/?q=khazanah bahasa

Creswell, J. W. (2015). Penelitian Kualitatif dan Desain Riset (Memilih diantara Lima Pendekatan). Yogyakarta: Pustaka Pelajar.

Divita, M. R., \& Puspitasari, D. G. (2011). Perancangan Buku Cerita Anak PopUp. Humaniora, 2(2), 1107-1118.

Hawarya, Y., \& Warso, A. W. D. D. (2014). Pengembangan Pop-up Module Pembelajaran Biologi pada Materi Pencemaran dan Pelestarian Lingkungan untuk Siswa SMA kelas X. JUPEMASI-PBIO (Jurnal Penelitian Mahasiswa Pendidikan Biologi), 1(1), 139-143.

Hudaa, S., Setiyadi, D. B. P., Laxmi Lydia, E., Shankar, K., Nguyen, P. T., Hashim, W., \& Maseleno, A. (2019). Natural language processing utilization in healthcare. International Journal of Engineering and Advanced Technology, $8(6 \quad$ Special Issue 2), 1117-1120. https://doi.org/10.35940/ijeat.F1305.0886S219

Hudaa, S. (2018). Efektifitas Pembelajaran Bahasa Indonesia Menggunakan 
Pendekatan Student Active Learning di Jurusan Manajemen Fakultas Ekonomi dan Bisnis UIN Syarif Hidayatullah Jakarta. BAHASTRA, 38(1), 69-74. https://doi.org/10.26555/bahastra.v38i1.7300

Lestari, R. N. F. I. (2016). Buku Pop-Up Untuk Pembelajaran Bercerita Siswa Sekolah Dasar. Perspektif Ilmu Pendidikan, 30(1), 21-26. https://doi.org/10.21009/pip.301.3

Karras, J. T., Fuller, C. L., Carpenter, K. C., Buscicchio, A., McKeeby, D., Norman, C. J., Parcheta, C. E., Davydychev, I., \& Fearing, R. S. (2017). Popup mars rover with textile-enhanced rigid-flex PCB body. Proceedings IEEE International Conference on Robotics and Automation, 5459-5466. https://doi.org/10.1109/ICRA.2017.7989642.

Kim, H., Fiore, A. M., Niehm, L. S., \& Jeong, M. (2010). Psychographic characteristics affecting behavioral intentions towards pop-up retail. International Journal of Retail and Distribution Management, 38(2), 133-154. https://doi.org/10.1108/09590551011020138

Lewin, K. (1946). Action Research and Minority Problems. Journal of Social Issues, 2(4), 34-46. https://doi.org/10.1111/j.1540-4560.1946.tb02295.x

Lismayanti, M. \& Hamidah, E. A. (2016). Pengembangan Buku POP UP Sebagai Media Pembelajaran Pada Materi Crustacea Untuk SMA kelas X. Jurnal Penelitian Universitas Jambi Seri Sains, 18(1), 44-48.

Mahnun, N. (2012). Media Pembelajaran (Kajian terhadap Langkah-langkah Pemilihan Media dan Implementasinya dalam Pembelajaran). An-Nida': Jurnal Pemikiran Islam, 37(1), 27-35.

Mediyawati, N., Lustyantie, N., \& Emzir, E. (2019). Media: Designing A Model Of IFL Learning Materials for Foreign Workers. Jurnal Cakrawala Pendidikan, 38(1), 75-89. https://doi.org/10.21831/cp.v38i1.22245

Miles, M. B., \& Huberman, M. A. (2012). Analisis Data Kualitatif: Buku Sumber Tentang Metode-Metode Baru. Jakarta: Universitas Indonesia Press.

Moleong, L. J. (2017). Metodologi Penelitian Kualitatif (Edisi Revisi). Bandung: PT. Remaja Rosda Karya.

Mulyaningsih, I., \& Itaristanti, I. (2018). Pembelajaran Bermuatan HOTS (Higher Order Thinking Skill) di Jurusan Tadris Bahasa Indonesia. Indonesian Language Education and Literature, 4(1), 114-128. https://doi.org/10.24235/ileal.v4i1.2970.

Putri, Q. K., Pratjojo, P., \& Wijayanti, A. (2019). Pengembangan Media Buku Pop-Up untuk Meningkatkan Kemampuan Menyimak Tema Menyayangi Tumbuhan dan Hewan di Sekitar. Jurnal Pedagogi dan Pembelajaran, 2(2), 169-175. https://doi.org/10.23887/jp2.v2i2.17905.

Qi, J., \& Buechley, L. (2010). Electronic popables: Exploring paper-based computing through an interactive pop-up book. TEI'10 - Proceedings of the 4th International Conference on Tangible, Embedded, and Embodied Interaction, 121-128. https://doi.org/10.1145/1709886.1709909.

Rahardi, R. K. (2017). Language Phatic in Specific Culture Perspective. 1st International Conference on Education, Language, and Arts, 1165-1174.

Saddhono, K. (2015). Integrating culture in Indonesian language learning for foreign speakers at Indonesian universities. Journal of Language and Literature, 6(2), 273-276. https://doi.org/10.7813/j11.2015/6-2/58

Soewarno, Hasmiana, \& Faiza. (2005). Kendala-Kendala yang Dihadapi Guru dalam Memanfaatkan Media Berbasis Komputer di SD Negeri 10 Banda 


\section{Indonesian Language Education and Literature \\ e-ISSN: 2502-2261 \\ http://www.syekhnurjati.ac.id/jurnal/index.php/jeill/ \\ Vol. 6, No. 2, Juli 2021, $248-261$}

Aceh. Jurnal Pesona Dasar, 2(4), 28-39.

Sugiyono. (2012). Metode Penelitian Kuantitatif, Kualitatif dan $R \& D$. Bandung:Alfabeta. https://doi.org/10.1017/CBO9781107415324.004

Ummi, H. U., \& Mulyaningsih, I. (2016). Penerapan Teori Konstruktivistik pada Pembelajaran Bahasa Arab di IAIN Syekh Nurjati Cirebon. Indonesian Language Education and Literature, 1(2), 162-172.

Vate-U-Lan, P. (2012). An Augmented Reality 3D Pop-up Book: The Development of A Multimedia Project for English Language Teaching. Proceedings - IEEE International Conference on Multimedia and Expo, 890-895. https://doi.org/10.1109/ICME.2012.79.

Wang, C. C., Hennek, J. W., Ainla, A., Kumar, A. A., Lan, W. J., Im, J., Smith, B. S., Zhao, M., \& Whitesides, G. M. (2016). A Paper-Based Pop-up Electrochemical Device for Analysis of Beta-Hydroxybutyrate. Analytical Chemistry, 6326-6333. https://doi.org/10.1021/acs.analchem.6b00568.

Wharton, T. (2009). Pragmatics and Non-Verbal Communication. Cambridge: Cambridge University Press. https://doi.org/10.1017/CBO9780511635649.

Widayati, A. (2014). Penelitian Tindakan Kelas. Jurnal Pendidikan Akuntansi Indonesia, 6(1), 87-93. https://doi.org/10.21831/jpai.v6i1.1793.

Zainorrahman, Z., Azizah, L. F., \& Kadarisman, K. (2019). Pengembangan Media Berbasis Pop Up Book untuk Pembelajaran IPA di MTs Raudhatut Thalibin. Alpen: Jurnal Pendidikan Dasar, 2(2), 99-106. https://doi.org/10.24929/alpen.v2i2.21. 